\title{
Agribusiness Strategy: Adding Value to the Mushroom Value Chain
}

\author{
Kwaku Ahenkora ${ }^{1}$, Arthur Dissou Yarhands ${ }^{2}$, Stephen Banahene ${ }^{3}$ \\ ${ }^{1}$ Department of Logistics, Christian Service University College, Kumasi, Ghana \\ Email:k.abenkora@yaboo.co.uk \\ ${ }^{2}$ Department of Computer Science, Christian Service University College, Kumasi, Ghana \\ Email:day1981boy@yaboo.com \\ ${ }^{3}$ Department of Corporate Strategy, Business School, Christian Service University College, Kumasi, \\ Ghana, Email: sbanabene@yahoo.co.uk
}

\begin{abstract}
Strategy should begin with the understanding of customer needs which can be determined through perceptions of channel partners or direct research. In line with this, the study conducts a qualitative value chain audit of the mushroom industry with a view to understanding priorities. Structured and semi-structured interviews were conducted with value chain players of the 'mushroom growers and export association'. Value chain participants prioritised changing customer perceptions to improve demand, and to grow the market through penetration and the management of factors that influence the marketing mix, and the provision of quality inputs to improve production and influence the need to address the problem of access to finance and a strong association that advocates for matters of the industry. The study concludes that qualitative value chain analysis of participants' perspectives provides the means for understanding of priority activities for value creation. The study recommends further quantitative value chain analysis that measures the actual value that prioritised value chain activities could generate.
\end{abstract}

Keywords: Agribusiness; mushroom; value chain, strategy, qualitative.

\section{Introduction}

Agriculture contributes the largest share of Ghana's Gross Domestic Product (GDP) and over $50 \%$ of the population are directly engaged in the sector (MOFA, 2009). In addition to modernising the traditional agriculture sector, agribusiness strategies include the development of non-traditional crops for the domestic and export market. The potential of mushrooms, as a non-traditional crop, to generate income for farmers and the nutritional and medicinal attributes of mushrooms are widely recognised (Gateri et al., 2009). The government of Ghana's support for mushroom production and the establishment of the erstwhile National Mushroom Project in the 1990s aimed to exploit these advantages. However, commercialization of mushrooms in Ghana and expectations of cultivation and local income generation potential are not being achieved in practice.

The strategic objectives of Ghana's food and agriculture sector policy include improved growth in income, increased competitiveness and enhanced integration into domestic and international market and improved institutional coordination (MOFA, 2009). In the neoliberal climate of the day and its competitive environment, the need for industries to ensure value in order to gain and retain public/ stakeholder support compels agriculture industry and commodity association leaders to examine the means by which value is created or lost. The value chain framework is an approach for breaking down the sequence (chain) of business functions into the strategically relevant activities through which utility is added to products and services in a business or an industry. Value chain analysis is undertaken in order for one to understand the behaviour of costs and the sources of differentiation (Shank \& Govindarajan, 1993). Value chain analysis of the business or industry is also used by strategic analysts to understand vulnerabilities, discover and evaluate opportunities for expansion, look for increased margins, understand more profoundly suppliers, customers and competitors (Levicki, 2003). 
Studies on competitive commercial agriculture in Africa using value chain analysis of selected commodities recommend the analysis of the qualitative features of the value chain such as the institutional and organisational factors that affect costs and shape relationships among the value chain actors (Keyser, 2006).

Strategy should begin with the understanding of customer needs since the service and anticipation of customer needs are ways of winning in the global market. The needs of these customers can be determined through perceptions of channel partners or direct research, especially in the case of domestic value chains (Henning et al., 2008). Although mushroom cultivation holds good economic promise, not much is known about the vulnerabilities of the industry and the understanding of the mushroom value chain has been recognised as a strategic imperative (Ahenkora, 2011). The purpose of this study, therefore, is to conduct a qualitative value chain audit of the mushroom industry with a view to the understanding of the vulnerabilities and priorities of the value chain players. This study is part of a series of interventions aimed at improving the strategies and competitiveness of the mushroom industry.

\section{Methodology}

The focus of the study was for the researcher to understand the perspectives of the mushroom value chain players who are members of the Ghana Mushroom Growers and Exporters Association of Ghana (MUGREAG). MUGREAG is currently organised into two sectors, the Southern and the Northern Sectors. As part of two separate stakeholder meetings organised in venues at the two sectors, members of the association were asked to fill in structured questionnaires on optional basis. The factors for research considerations were derived from document analysis of the strategic plan and issues facing the mushroom industry. The Southern sector meeting attracted thirty-five (35) participants who had undergone training on mushroom cultivation but had not started to operate; they were politely asked not to take part in the interview. The questionnaires were explained to respondents and facilitators were available to assist interviewees in filling the forms. Twenty five (25) and thirty-five 35 forms were returned at the Northern and Southern sectors, respectively. Data were analysed using Statistical Package for the Social Sciences. Percent ranking scores were used. Eighty-five percent $(85 \%)$ of respondents were males while $15 \%$ were females and $44 \%$ of respondents were 50 years or more while $10 \%$ were under 29 years of age .

Table 1

Characteristics and operations of respondents

\begin{tabular}{|c|c|c|c|}
\hline Description & Percent & Description & Percent \\
\hline Sex & & $\begin{array}{l}\text { Years in mushroom } \\
\text { production/ business }\end{array}$ & \\
\hline Male & 85 & Less than 1 year & 24 \\
\hline Female & 15 & $1-4$ years & 24 \\
\hline Age & & $5-10$ years & 32 \\
\hline Under 29 & 10 & $11-20$ years & 20 \\
\hline $30-39$ & 16 & & \\
\hline $40-49$ & 30 & $\begin{array}{l}\text { Reason for involvement in } \\
\text { industry }\end{array}$ & \\
\hline $50-59$ & 22 & $\begin{array}{l}\text { Knowledge of profit } \\
\text { potential }\end{array}$ & 30 \\
\hline Over 60 & 22 & Through Govt. Programmes & 10 \\
\hline
\end{tabular}




\begin{tabular}{|c|c|c|}
\hline $\begin{array}{l}\text { Contribution of mushroom to business } \\
\text { activities }\end{array}$ & & Persuaded by friends/ family \\
\hline Sole product/ service of business & 40 & Personal interest \\
\hline Provide additional products/ services & 60 & $\begin{array}{l}\text { Only available means of } \\
\text { self- employment }\end{array}$ \\
\hline Involvement in value chain functions & & \\
\hline Produce and sell mushroom spawn & 10 & $\begin{array}{l}\text { Percentage of income from } \\
\text { mushroom }\end{array}$ \\
\hline Grow mushrooms & 21 & $70-100 \%$ \\
\hline Grow and sell mushrooms locally & 40 & $51-69 \%$ \\
\hline Process mushrooms & 3 & $40-50 \%$ \\
\hline Mushroom wholesaling & 6 & $20-39 \%$ \\
\hline Mushroom retailing & 5 & $1-19 \%$ \\
\hline Train others on mushroom production & 16 & \\
\hline
\end{tabular}

Semi-structured interviews were also conducted with MUGREAG members on their perspectives on selected factors (physical, socio-cultural, legal, economic and competitive) on the mushroom marketing mix (product, price, place, promotion, process management).

\section{Results}

The results were presented on the basis of respondents' involvement in the mushroom industry, their perspectives on problems facing the industry and priority solutions for value chain activities.

\subsection{Involvement in the mushroom value chain}

The results showed that $40 \%$ of respondents relied solely on mushrooms while the rest provided additional products or services to the business. In terms of specific involvement with the industry, a large number of respondents (40\%) grew and sold mushrooms locally; about $21 \%$ grew mushrooms and
$16 \%$ trained others in mushroom production. Quite a few produce and sell mushroom bags and a minimal number are involved in processing, mushroom wholesaling or retailing activities. More than half of the respondents have been in the mushroom agribusiness for 5 years and almost a quarter are just under a year in the business. Reasons for involvement in the business were dominated by the knowledge of the business profit potential (30\%) and personal interest (30\%). Very few are in the business as the only means of employment (5\%). More than a quarter of respondents indicate that they derive $70-100 \%$ of their income from mushrooms and over $60 \%$ of people derive more than half of their income from mushroom business activities.

\subsection{Core Problems of the mushroom industry}

Respondents were asked to rank, from the most problematic to the least problematic, five problemsout of 13 that included access to finance, waning interest in the mushroom business, lack of access to and to set up farms, lack of training, 
lack of weather, temperature, moisture control equipment, consumer attitudes towards cultivated mushrooms, lack of reliable ready market for mushrooms, lack of support from government; lack of consistent mushroom production, a weak national mushroom association, lack of cooperation among growers, sellers, researchers and government agencies The results on percent ranking showed that the five problems, from the most to the least important, were access to finance, lack of support from the government, lack of reliable source and supply of certified spawns / bags, unfavourable consumer attitudes towards cultivated mushroom and lack of weather / temperature / moisture control equipment.

Table 2

Problems and priority solutions for mushroom value chain activities

\begin{tabular}{|c|c|c|}
\hline Core problems of the mushroom industry & Rank & Percent \\
\hline Access to finance & 1 (most problematic) & 53.5 \\
\hline Lack of support from government & 2 & 14 \\
\hline Lack of reliable source and supply of certified spawns & 3 & 14 \\
\hline Consumer attitudes towards cultivated mushroom & 4 & 11.6 \\
\hline Lack of weather/temperature/moisture control & 5 (least problematic) & 11.6 \\
\hline \multicolumn{3}{|l|}{ Priority solutions for value chain primary activities } \\
\hline Provision of quality spawns and other inputs & 1 (most important) & 60.5 \\
\hline Increase production activities & 2 & 23.2 \\
\hline Improve marketing and trade & 3 & 13.9 \\
\hline Increase local consumption of cultivated mushroom & 4 & 18.6 \\
\hline Increase processing activities & 5 (least important) & 16.2 \\
\hline \multicolumn{3}{|l|}{ Priority solutions for value chain supporting activities } \\
\hline Strong association to advocate for matters of the industry & 1 (most important) & 44.2 \\
\hline Ease of procurement of input and supplies & 2 & 11.6 \\
\hline Improve technical know-how of growers, processors & 3 & 16.3 \\
\hline Improve business and management know-how of growers & 4 & 16.2 \\
\hline Improve access to modern production/processing technology & 5 (least important) & 20.9 \\
\hline \multicolumn{3}{|l|}{ Growing the mushroom market/industry } \\
\hline Selling raw/dried edible mushrooms to new customers & 1 (most important) & 32.6 \\
\hline Selling more raw/dried edible mushrooms to new & 2 & 23.3 \\
\hline selling medicinal mushroom to existing customers & 3 & 20.9 \\
\hline selling processed mushroom products to existing customers & 4 & 32.6 \\
\hline selling processed mushroom products to new customers & 5 (least important) & 20.9 \\
\hline \multicolumn{3}{|l|}{ Useful means of improving mushroom production } \\
\hline Availability of quality spawns & 1 (most important) & 34.9 \\
\hline Access to finance to put up cropping structures & 2 & 16.3 \\
\hline Knowledge of optimum conditions to maintain mushroom all year round & 3 & 27.9 \\
\hline
\end{tabular}




\begin{tabular}{llc} 
Farmer commitment to producing more & 4 & 6.9 \\
Government and institutional support for mushroom commercialisation & 5 (least important) & 25.5 \\
Improving demand and local consumption of mushrooms & & 51.2 \\
Changing perceptions about cultivated edible mushroom & 1 (most important) & 23.3 \\
Improving packaging and presentation of mushroom & 2 & 16.3 \\
Improving shelf life of raw mushrooms through canning & 3 & 16.3 \\
Increasing consumer choice by producing other mushrooms & 4 & 53.5 \\
Selling cultivated mushroom cheap & 5 (least important) & \\
\hline
\end{tabular}

The results of the priority solutions for value chain functional activities showed that respondents ranked from the most important to the least important; provision of quality spawns bags, increased production, improved marketing and trade, increase in local consumption of cultivated mushroom and increase in processing activities. Rankings of priority solutions for value chain activities show that respondents want to have a strong association that advocates matters of the industry (most important), followed by ease of procurement of input and supplies, improvement in technical and business know-how, and improved access to modern production/ processing technology (least important).

Following up on the priority solutions of value chain activities, the study looked at perspectives on improving mushroom production, marketing and local consumption. Respondents priorities for improving mushroom production, from the most to the least important, were the availability of quality spawns, access to finance to put up cropping structures, knowledge of maintaining optimum conditions for mushroom production all year round, farmer commitment to producing more and government support for mushroom commercialisation.
They were of the view that the sale of cultivated edible mushrooms to new customers is of primary importance to the growth of the mushroom market followed by the sale of cultivated edible mushrooms to existing customers, the sale of medicinal mushrooms to existing customers, the sale of processed mushroom products to existing customers and finally selling processed mushroom products to new customers. Critical to improving domestic demand and consumption of mushrooms is the need for stakeholders to change the perceptions about cultivated edible mushroom (ranked $1^{\text {st }}$ by half of the respondents), to improve packaging and presentation of mushroom $\left(2^{\text {nd }}\right)$, to improve shelf-life of raw mushrooms through canning $\left(3^{\text {rd }}\right)$, to increase consumer choice by the production of additional varieties of mushrooms and to sell cultivated mushroom cheaply $\left(5^{\text {th }}\right)$.

\subsection{Mushroom marketing mix}

The results of the semi-structured interview discussions were used to construct a mushroom marketing mix matrix.

Table 3

Mushroom marketing mix matrix

\begin{tabular}{|c|c|c|c|c|c|}
\hline Factors & Product & Price & $\begin{array}{l}\text { Place/ } \\
\text { Distribution }\end{array}$ & Promotion & $\begin{array}{l}\text { Process } \\
\text { management }\end{array}$ \\
\hline Physical Factors & $\begin{array}{l}\text { Seasonality affects } \\
\text { yield and size of } \\
\text { cultivated } \\
\text { mushrooms }\end{array}$ & $\begin{array}{l}\text { Price } \\
\text { fluctuations }\end{array}$ & $\begin{array}{l}\text { More outlets } \\
\text { required during } \\
\text { peak production. }\end{array}$ & $\begin{array}{l}\text { Price } \\
\text { undercutting at } \\
\text { peak times }\end{array}$ & $\begin{array}{l}\text { Handling } \\
\text { customers at } \\
\text { lean seasons }\end{array}$ \\
\hline $\begin{array}{l}\text { Socio-cultural } \\
\text { Factors }\end{array}$ & $\begin{array}{l}\text { Consumer attitude } \\
\text { towards cultivated } \\
\text { mushrooms }\end{array}$ & $\begin{array}{l}\text { Customers } \\
\text { attitude towards } \\
\text { price of }\end{array}$ & $\begin{array}{l}\text { Different outlets to } \\
\text { market to various } \\
\text { subcultures/ }\end{array}$ & $\begin{array}{l}\text { Personal selling } \\
\text { and campaigns to } \\
\text { influence buying }\end{array}$ & $\begin{array}{l}\text { Managing } \\
\text { consumer } \\
\text { expectancies }\end{array}$ \\
\hline
\end{tabular}




\begin{tabular}{|c|c|c|c|c|c|}
\hline & & $\begin{array}{l}\text { cultivated } \\
\text { mushrooms- } \\
\text { lower prices to } \\
\text { penetrate } \\
\text { market? }\end{array}$ & $\begin{array}{l}\text { different buying } \\
\text { habits }\end{array}$ & behaviour & $\begin{array}{l}\text { and acceptance } \\
\text { of cultivated } \\
\text { mushrooms }\end{array}$ \\
\hline $\begin{array}{l}\text { Legal and } \\
\text { Political Factors }\end{array}$ & $\begin{array}{l}\text { Label and } \\
\text { packaging } \\
\text { requirements. } \\
\text { Spawn and } \\
\text { cropping quality } \\
\text { standards } \\
\text { Lack of overt } \\
\text { government } \\
\text { support }\end{array}$ & $\begin{array}{l}\text { Varying retail } \\
\text { price to account } \\
\text { for packaging. } \\
\text { Premium pricing } \\
\text { for quality }\end{array}$ & $\begin{array}{l}\text { Minimum } \\
\text { restrictions on } \\
\text { channel members }\end{array}$ & $\begin{array}{l}\text { Ability to use } \\
\text { media. } \\
\text { Controls on } \\
\text { claims used in } \\
\text { ads. } \\
\text { Promotion with } \\
\text { institutional } \\
\text { stakeholders }\end{array}$ & $\begin{array}{l}\text { Stakeholder } \\
\text { management }\end{array}$ \\
\hline Economic factors & $\begin{array}{l}\text { Access to finance } \\
\text { affects production } \\
\text { and processing }\end{array}$ & $\begin{array}{l}\text { Price elasticity } \\
\text { of demand. } \\
\text { Purchasing } \\
\text { power } \\
\text { considerations }\end{array}$ & $\begin{array}{l}\text { Channel } \\
\text { management } \\
\text { Rural/ urban mix }\end{array}$ & $\begin{array}{l}\text { Funds to do } \\
\text { promotions. } \\
\text { Costs to reach } \\
\text { market segments. }\end{array}$ & $\begin{array}{l}\text { Sensitivity to } \\
\text { customer needs }\end{array}$ \\
\hline $\begin{array}{l}\text { Competitive } \\
\text { factors }\end{array}$ & $\begin{array}{l}\text { Cultivated versus } \\
\text { 'wild' } \\
\text { mushrooms } \\
\text { Imported products }\end{array}$ & $\begin{array}{l}\text { Competitors' } \\
\text { prices. } \\
\text { Number of } \\
\text { competitors }\end{array}$ & $\begin{array}{l}\text { Competitors } \\
\text { control of channel } \\
\text { members and } \\
\text { margins }\end{array}$ & $\begin{array}{l}\text { Competitors } \\
\text { promotional } \\
\text { expenditures } \\
\text { Competitors } \\
\text { choice of media }\end{array}$ & $\begin{array}{l}\text { Selling } \\
\text { solutions. } \\
\text { Managing } \\
\text { customer } \\
\text { objections. }\end{array}$ \\
\hline
\end{tabular}


Perceptions of the players in the industry showed that the influence of physical, socio-cultural, legal, political, economic and competitive factors on the marketing mix- product, price, place, promotion (hard Ps) and process management (soft P)......?. Seasonality is a key physical factor which affects mushroom production, leading to price fluctuations, distribution problems and customer frustrations which have to be managed. The major socio-cultural factor affecting the industry is consumer attitudes towards cultivated mushroom that also raises the issue of pricing; distribution and consumer expectancies. Legal and political factors affecting production and subsequently marketing mix elements include standardisation and government support for commercialisation of mushrooms. Economic factors are perceived to influence urban and rural demand for cultivated mushrooms, channel management and promotional activities. Locally cultivated mushrooms compete with natural mushrooms and imported fresh and processed mushroom products. Competitive pricing becomes an issue as well as the need for farmers to monitor the competition and to promote or build the local brand.

\section{Discussion}

The value chain approach is a business oriented approach which aims at making use of the best values and views of the organisation or industry as a sequential process of valuecreating activities; creating value for buyers that exceeds the costs of production (Dess et al., 2005). The value chain is different from different firms and industries (Porter, 1985) and the primary activity chain adopted for this study, input provision, production, processing, marketing and trade and consumption, differs from the general agriculture value chain stages (input supply, farm production, assembly, processing and logistics) adopted by Keyser (2006) but it is similar to the grasscutter value chain of Weidinger (2005).

The perspectives of the mushroom value chain participants in this study showed that mushrooms make an appreciable contribution to businesses and income levels and also suggest that value chain participant's priorities should constitute the informed choice for value addition. The success of private firms is only the beginning of successful value chain development that has to be followed by the creation of a vibrant value chain where all stakeholders are focused on the needs of the market and create collaborative business models that promote equitable growth (Henning et al., 2008).
The value chain approach starts with the market and consumer demands and develops promotional and production strategies in a deductive manner and intends to increase value; and in the developmental context, considers where value is added and who benefits (Weidinger, 2005).

In his methodology for value chain analysis for competitive commercial agriculture in Africa, Keyser (2006) observed that quantitative value chain analysis (focuses on the amount of money a buyer is willing to pay for a firm's output and in an open economy this price is determined competitively and flows upstream from the consumer to each producer and marketing company involved in the growing, collection transformation, and delivery of that commodity to itsterminal market) must be couched within an analysis of qualitative factors. Value chain participants' perspectives on vulnerabilities and priorities are, therefore, important. Along the mushroom value chain, participants advocate the changing of consumer perceptions about cultivated edible mushrooms to improve demand, emphasise market penetration with cultivated edible mushrooms and raise concerns on the influence of various factors on the marketing mix, to access finance for production and increased government support for commercialisation of mushrooms, and the input provision of quality spawns (bags). While traditional value chain analysis focuses only on primary activities, this study looked at supporting activities where participants felt that a strong association that advocates matters of the industry is vital to a successful value chain development. Therefore, the ongoing efforts to develop farmer-based organisations as part of a strategy for improving small holder access to services merits continuation (MOFA, 2009). Review of studies in Kenya also recognises the important role of strong associations in the cultivation and commercialisation of edible mushrooms (Gateri et al., 2009).

\section{Conclusion}

Strategy can begin with the understanding of customer needs through the perceptions of channel partners. This study conducted an audit of the mushroom value chain, and participants clearly articulated their priorities that included: the changing of customer perceptions to improve demand, the growth of the market through penetration, the management of factors that influence the marketing 
mix, the provision of quality inputs to improve production and the need for stakeholders to address the problem of access to finance, a strong association that advocates matters of the industry. The study concludes that qualitative value chain analysis of participants perspectives provided the means for the understanding of priority activities for value creation.

\section{Recommendation}

The study recommends qualitative value chain audit as an important strategic tool that can be used to improve value chain competitiveness based on informed choices. The current study could have benefited from the overall perspectives of a larger number of participants - future work should take this into consideration. However, the results of the study provides the foundation for quantitative value chain analysis that measures the actual value that prioritised value chain activities would generatenumber of participants - future work should take this into consideration. However, the results of the study provides the foundation for quantitative value chain analysis that measures the actual value that prioritised value chain activities would generate.

\section{References}

Ahenkora, K., (2011). "'Moving the Mushroom Industry Forward: Strategic Imperatives"First National Mushroom Stakebolder Conference, Erata Hotel, Accra, Ghana, 12 $2^{\text {th }}$ May, 2011.

Dess, G.A., Lumpkin, G.T. and Taylor, M.L.,(2005). Strategic Management: Creating Competitive Advantage, McGraw-Hill Irwin, New York.
Gateri, M.W., Muriuki, A.W., Waiganjo, M.W. and Ngeli,P., (2009)Cultivation and Commercialisation of Edible Mushrooms in Kenya: A Review of Prospects for Smallholder Producers, Acta Hort., Issue 806, pp.473-480.

Keyser, J.C., (2006). Background Paper for the Competitive Commercial Agriculture in Sub-Sabaran Africa (CCAA) Study, World Bank.

Levicki, C. (2003). Strategy Workout: Analyse and Develop Your Fitness for Business, Prentice Hall, Harlow.

MOFA, (2009). Food and Agriculture Sector Development Policy (FASDEP II), Ministry of Food and Agriculture. Accra, Ghana.

Porter, M., (1985). Competitive Strategy, Free Press, New York.

Shank, J.K. and Govindarajan, V., (1993). Strategic cost management: the New Tool for Competitive Advantage, Free Press, New York.

Weidinger, R., (2005). Introduction into the Value Chain of Grasscutter, Proceedings of the International Forum on Grasscutter. Institute of Local Government Studies, Accra, Ghana. $12-16^{\text {th }}$ December, 2005. 